YAK 378

ББК 74.58

DOI 10.22394/1682-2358-2018-6-72-77

L.V. Karasik, lecturer of the Law and Social Provision Department, Voronezh Economics and Law Institute

\section{CHALLENGES \\ AND OPPORTUNITIES OF INNOVATION DEVELOPMENT IN THE RUSSIAN HIGHER EDUCATION SYSTEM}

The current aspects of applying innovation activity in the system of Russian higher education are considered. The author highlights problematic issues of imperfection of the current legislation. The prospects of legal regulation and effective implementation of innovative processes in the system of higher education, as well as foreign experience of innovative educational activities are analyzed.

Key words and word-combinations: innovation in education, innovation activities, the system of higher education, foreign experience, Voronezh.
A.B. Карасик, преподаватель кафедрьг права и организачии сочиального обеспечения Воронежского экономико-правового института (email:karasik.mila@bk.ru)

\section{ПРОБАЕМЫ \\ И ПЕРСПЕКТИВЫ РАЗВИТИЯ ИННОВАЦИЙ В РОССИЙСКОЙ СИСТЕМЕ ВЫСШЕГО ОБРАЗОВАНИЯ}

\footnotetext{
Аннотация. Рассматриваются актуальные аспекты применения инновационной деятельности в системе высшего российского образования. Выделяются проблемные аспекты несовершенства действующего законодательства. Анализируются перспективы правовой регламентации и эффективной реализации инновационных процессов в системе высшего образования, а также зарубежный опыт инновационной образовательной деятельности.

Ключевые слова и словосочетания: инновации в образовании, инновационная деятельность, система высшего образования, зарубежный опыт, Воронеж.
}

$\mathrm{B}$ шества является человеческий капитал, перј ставАяющий собой необходимый Аля развития мюбого государства потенциал, который скмадывается из таких основных факторов, как интемект, знания и опыт. Именно система высшего образования формирует необхоАимый фундамент Амя конкурентоспособных трудовых ресурсов современного социума.

На современном этапе обшественного развития такие важные категории, как иннова- 
ции и инновационная деятельность, практически «захватили» жизнь общества. Почти невозможно встретить какую-либо отрасль, не связанную с реализаџией инновационной деятельности и инноваций. Несмотря на передовой характер указанных современных феноменов, возникает множество теоретических и практических вопросов формирования научной концепџии инновационной Аеятельности и ее эффективного внеАрения в учебный проџесс и производство.

В данном контексте весьма показателен исторический опыт зарубежкных стран, не претерпевших множества кризисных экономических периодов и стабильно развивавшихся с учетом современных передовых технологий. Представмяется вполне цогичным рассмотреть некоторые аспекты положительного опыта использования инноваций и инновационной деятельности в Аругих государствах, чтобы обратить внимание законодателя на возможные пути решения сложных проблемных вопросов, связанных с инновационной деятельностью, поскольку инноваџии в российском образовании, в силу определенного консервативного мировоззрения законодателя, не получили соответствующей нормативно-правовой платформы для своего развития. На наш взгляА, именно государство Аолжно инициировать изменение в действующее законодательство относительно инновационной деятельности, поскольку от этих категорий зависит общий уровень развития образования в государстве и верное толкование указанных терминов.

Заскуживает внимания опыт зарубежных стран, где стало возможным и очевидным успешное развитие и использование инновационной деятельности при «эффективном» законе, который помогает формировать соответствующую государственную социально-экономическую политику и добиваться высоких показателей в высшем образовании. Это связано с тем, что вопросы правового регулирования и формирования основных стратегических инновационных направлений решаются искцючительно на государственном уровне при осушествлении им своих основных функций. Аیя возможного прояснения рассматриваемой проблематики осуществим анациз международной практики. Например, в таких развитых странах как Великобритания, США, Япония, Китай вопросам правового закрепления инновационных образовательных процессов законодателем уделено должное внимание, чего нельзя сказать о Российской Федерации. В перечисленных странах особенно тщательно прорабатываются вопросы правового, финансового регулирования, защиты интелмектуальной собственности, развитию технопарковых структур, объединения усилий учебных заведений и научно-исследовательских центров и т.А.

Отметим, что иностранные законодатели предоставцяют права изобретатемям получать «инновационную ренту», то есть плату за пользование изобретением, что стимулирует развитие и создание инноваций, в том числе и в сфере высшего образования, поскольку именно этот сегмент является первичным и направлен на формирование передовых кадров, способных работать с новыми технологиями [1, с. 8-9]. В Аругих государствах дмя быстрого развития национальной инновационной деятельности приняты «адекватные» налоги Аля вновь входящих на рынок преАприятий, активно функщионирующих в инновационном направлении [2, с. 69] .

Во многих странах научно-исследовательская работа - это престижный и уважаемый виА деятельности. Например, ОксфорА тесно сотрудничает с 
исследовательскими институтами, компаниями и различными сферами бизнеса Вемикобритании, США, Ближнего Востока, Индии, Южной Африки, Аатинской Америки. При университете созданы сотни малых инновационных преАприятий с бюджетом в 14 мирА домаров. По всей вероятности, сфера инноваџионного развития российского высшего образования пока недооџенивается как на федеральном, так и на региональном уровнях [3] .

Основной проблематикой современной российской науки и образования становится отсутствие внятного, устоявшегося категорийно-понятийного аппарата, который может обеспечить исследуемый институт соответствующей терминологией; часто Аюбое нововведение в образовании именуют инновацией, не раскрывая, что же представцяет собой этот термин в действительности, и это позволяет проводить разцичного рода проекты, не имеющие ни одного сущностного признака инновации.

Аанные обстоятельства создают устойчивое общественное мнение банальности и общепонятности относительно высокой соџиальной востребованности инноваций. С этим согласиться нельзя, так как подобные сущностно-важные категории должны четко осознаваться как самим государством, так и всем обществом, Аля эффективности их применения и рационацьного использования в системе высшего образования.

Многие современные ученые критикуют сложившийся в современной правовой системе значимый пробел в действующем законодательстве и выступают за принятие еАиного, Аоработанного и соответствующего современным реалиям понятийного аппарата, способного обеспечить инновационную Аеятельность в системе высшего образования эффективным инструментарием. Не вызывает сомнений необходимость формулировки общего понятия инновации, которое станет определенной основой дия последующих терминов, адаптированных непосредственно к каждой спеџиализированной сфере жизнедеятельности, в том числе и системе высшего образования [4, с. 140] .

Отсутствие единой конџепџии правового регулирования инноваций и инновационной деятельности в системе высшего образования не позволяет на желаемом уровне привлекать инвестиции в сферу реализации образовательной деятельности в России. Из-за низкого уровня осуществления инновационной деятельности в вузах рейтинг российского образования значительно уступает зарубежному, провоџируя отток перспективных кадров. Это обусмовливает необходимость разработки более жестких критериев поступления в российские вузы, но не решает проблему оснашенности учебных заведений и соответствующей образовательной базы, поскольку студенты приходят в вуз в первую очередь Аля того, чтобы научиться, а не научить.

Необходимо учитывать, что будущее современного высшего образования зависит от качественного правового обеспечения инновационной деятельности, которую могут использовать в своем арсенале ведущие вузы России. На рациональность данных выводов указывает ст. 71 Конституции РФ, согласно которой правовое регулирование интемлектуальной собственности явцяется правовой базой инновационного процесса и отнесено к сфере ведения Российской Федерации.

ОАнако нельзя утверждать, что Российское государство относится безразмично к рассматриваемой тематике. Напротив, повышение качества высшего

74 Bulletin of the Volga Region Institute of Administration • 2018. Vol. 18. № 6 
образования обозначено в виде приоритетной задачи Конџепџии развития образования на 2016-2020 гг., утвержденной Правительством РФ 29 декабря 2014 г. (№ 2765-р). К числу приоритетных задач государственной инноваџионной политики в сфере образования относится эффективное развитие высшего образования в РФ, направленное на формирование конкурентоспособного кадрового потенщиала, способного реализовать себя в России и достойно представить страну на международной арене. Только высокое качество системы российского образования и науки в современных условиях способно стать желаемой характеристикой мюбого вуза и научного центра, обеспечив их уверенность в своем будушем, поскольку именно от такого рода деятельности в значительной степени зависят объем государственного заказа на подготовку специалистов, бюджетного финансирования и, соответственно, рейтинг вуза.

В вопросах инноваций в системе высшего образования наиболее рационально и эффективно развиваются региональное законодательство и соответствуюшая политика. Так, субъекты РФ, исходя из определенной сферы правового регулирования и территории действия, сами определили, что же считать инновацией. Например, в Томской и Оренбургской областях считается, что инновация - результат инновационной деятельности, в Саратовской и Мурманской - что инновация явмяется результатом научной или творческой деятельности, в Тверской и Воронежской областях инновацией называется нововведение и т.А. Около шестидесяти российских регионов приняли соответствующие законы, посвященные инновационной деятельности в той или иной области. В настоящее время многие высшие учебные заведения при соответствующей подАержке органов государственной власти субъектов Федерации и органов местного самоуправления приобретают статус региональных научных инновационных центров. По версии агентства «Эксперт РА», в 2017 г. в сто кучших вузов России вошии и воронежские вузы [5]. По информационным данным Аепартамента образования, науки и молодежной политики, Воронежская область обладает развитым интемлектуальным потенџиалом и занимает второе место в Центральном федеральном округе по количеству обучающихся в высших учебных заведениях.

Исходя из статистических данных, на тысячу человек, проживающих в г. Воронеже и Воронежской обцасти приходится около пятидесяти студентов, в регионе работает более 25 организаџий высшего образования - государственных и частных вузов, а также их филиалов. Работа сферы высшего образования Воронежской области высоко оџенивается Министерством образования и науки РФ. По информационным данным мониторинговых систем, в регионе функционируют «эффективные» высшие учебные заведения, число же «неэффективных» образовательных учреждений в 2017 г. заметно уменьшимось [5].

Важнейшими показатемями эффективности высшего образовательного учреждения являются: а) образовательная деятельность; б) научно-исследовательская деятельность; в) международная и финансово-экономическая деятельность; г) инноваџионная деятельность. Это связано с тем, что условия Аля получения качественного образования и востребованности выпускников работодателями во многом зависят от рейтинга вуза и уровня развития образования и науки, в том числе инноваџионной, которая позволяет выделить деятельность образовательного учреждения и определить его конкурентоспо- 
собность. Целесообразно уточнить, что такой важнейший фактор образовательного процесса, как уровень научно-исследовательской активности, также зависит от «инновационной активности и инфраструктуры».

На данном этапе можно констатировать увеличение количества совместных инновационных научных проектов воронежских университетов, институтов с крупными предприятиями. Указанные тенденции остро необходимы мюбому развиваюшемуся региону, поскольку без внедрения инновационных научных разработок в рыночную среду они могут потерять свою значимость и эффективность. Сегодня многие воронежские вузы при соответствующей финансовой и административной подАержке региональных властей смогли создать вокруг себя полноценную инновационную инфраструктуру - технопарки, бизнес-инкубаторы, центры коммективного пользования, что определенным образом подталкивает местные промышиенные компании к сотрудничеству с образовательными учреждениями.

Запланированный рост инновационной активности в воронежских вузах во многом обусловлен деятельностью вузов в рамках работы федеральных технологических платформ - объединений государственных, обшественных институтов и бизнес-структур, основанных на принџипах государственно-частного (некоммерческого) партнерства. ГАавное направление подобной деятельности - ведение научных исследований по приоритетным направлениям технологического развития и применение научных достижений в производстве с помошью государственно-частного партнерства. Этот подхоА представляется весьма перспективным дмя развития инноваций в образовании и науке, если он будет развиваться и расширяться. В обцастной реестр инновационных проектов и научно-технических разработок включены несколько сотен проектов, что позволяет решать соџиальные задачи, улучшать кадровый потенциал региона и формировать перспективные направления Аля выбора обучающимися будущих профессий.

ОАнако на обеспечение инновационного развития высшего образования

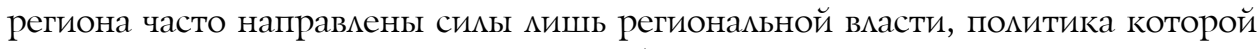
ориентирована на развитие науки в области, с учетом достижений молодых ученых и подлержкой их инициатив [6, с. 210]. В подобном случае более рационально разрабатывать и реализовывать совместные проекты и программы, принимать соответствующие правовые акты, направленные на развитие сектора инноваџионного высшего образования совместно с федеральными органами государственной власти. Это позволит формализовать и обеспечить эффективность внедрения новых научных разработок не только в одном конкретном регионе, но и во всей стране. Перспективы развития научной и инновационной деятельности принадлежат регионам России, что, на наш взгляА, не совсем верно, поскольку именно государство на феАеральном уровне Аолжно формировать соответствующую конџепџию инновационной политики в сфере высшего образования дмя џелостного, единообразного и эффективного развития.

Развитию инновационных методов осуществления образовательной деятельности в регионе в значительной степени помогает международное сотрудничество [7, с. 488]. В Аанной сфере Воронежская обцасть стремится к активизаџии совместной деятельности с Японией, Германией и рядом других стран, так как сегодня в передовых зарубежных странах выработана стра-

76 Bulletin of the Volga Region Institute of Administration • 2018. Vol. 18. № 6 
тегия, которая учитывает изменения в быстроразвивающихся общественных отношениях, оџенивает знание, опыт и возможности внеАрения инновационных продуктов научной деятельности в высших учебных заведениях.

Зарубежное высшее образование представляется более успешным еше и потому, что в рамках правового поля верно поставцена цель - не просто Аать обучающимся базовые знания, соответствующие уровню высшего образования, а разработать новые направления, которые позволят развивать инновационную Аеятельность и привлекать к ней обучающихся дяя получения соответствующих инновационных продуктов и передовых результатов.

В качестве перспективного решения проблематик, обозначенных в Аанной статье, важно акцентировать внимание на Модельном законе «Об инновационной деятельности», принятом для стран СНГ на 27-м пленарном заседании Межкпарламентской Ассамблеи государств - участников Содружества Независимых Государств. Аанный Закон служит определенной основой Амя разработки специальных нормативно-правовых актов государств-участников СНГ в секторе реализации инновационной деятельности и направлен на повышение конкурентоспособности в экономической сфере стран СНГ за счет применения научно-технических достижений, технологий и других результатов научно-технической деятельности.

При отсутствии в национальном законодательстве правовых норм, посвященных инновационной деятельности в системе высшего образования, возможно применение отдельных положений Модельного закона «Об инновационной деятельности» (п. 3, ст. 14) или же международных договоров и соглашений, ратифицированных парламентами государств - участников СНГ.

Принятие Федерального закона «Об инновационной деятельности в Российской Федерации» в сочетании с упомянутым Модельным законом Аля стран в составе СНГ позволит детально урегулировать общественные отношения в этой сфере деятельности, а также позволит сформировать надлежащее правовое регулирование инновационных проџессов в системе высшего образования и улучшить экономический климат в Российском государстве.

\section{Библиографический список}

1. Калятин В.О., Наумов В.Б., Никифорова Т.С. Опыт Европы, США и Индии в сфере государственной поддержки инноваций // Российский юридический журнал. 2011. № 1 (76). С. 8-9.

2. Костюкевич C.B. Инновации: подход современных западных авторов в контексте российского опыта // Alma mater. 2011. № 4. С. 69.

3. Якимова Т.Б. Сравнительный анализ инновационной активности вузов в России и за рубежом // Современные научные исследования и инновации. 2014. № 10, ч. 2. URL: http.web. snauk.ru/issues/2014/10/39552

4. Беличкая А.В., Хаустов Д.В. Правовой режим территорий, созданных с целью развития инноваций // Закон. 2013. № 6. С. 140-147.

5. Высшая школа инноваций // Коммерсанть: Воронеж. URL: https:/www.kommersant.ru/doc/

6. Егоров E.B. Государственная научно-инновационная политика в РФ и высшей школе // Инновационное развитие высшей школы России: монография / под ред. Е.В. Егорова, С.А. Карева. М., 2010. С. 210.

7. Мушинский М.А. Стратегии, концепции, доктрины в правовой системе Российской Федерации: проблемы статуса, юридической техники и соотношения друг с другом // Юридическая техника. 2015. № 9. С. 488-495. 